\title{
Optimasi Suhu dan Waktu Deasetilasi Kitin Berbasis Selongsong Maggot (Hermetia ilucens) Menjadi Kitosan
}

\section{(Optimization of Temperature and Time of Chitin Deacetylation in Maggot Cells (Hermetia ilucens) to Produce Chitosan)}

\author{
Sri Wahyuni ${ }^{1 \star}$, Ranti Selvina ${ }^{2}$, Ridha Fauziyah ${ }^{2}$, Haryo Tejo Prakoso ${ }^{1}$, Priyono ${ }^{1}$, Siswanto ${ }^{1}$
}

(Diterima September 2019/Disetujui Mei 2020)

\begin{abstract}
ABSTRAK
Ketika peternakan Black Soldier Fly (BSF) sudah menjadi trend di Indonesia yang banyak bermunculan belakangan ini, terdapat peluang baru dalam memanfaatkan sampah sisa dari kegiatan tersebut. Salah satunya adalah exuviae yang dihasilkan dari metamorfosis belatung menjadi lalat. Exuviae BSF mengandung kadar kitin yang tinggi dan memiliki Cristalinity Index yang rendah sehingga memiliki potensi untuk dijadikan materi biopolimer baru. Oleh karena itu, penelitian ini bertujuan untuk mengubah kitin dari exuviae BSF menjadi kitosan dengan menggunakan proses deasetilasi yang dipengaruhi oleh temperatur dan lamanya proses deasetilasi. Variasi suhu dilakukan pada $50,60,70$, dan $80^{\circ} \mathrm{C}$ selama 12 jam sedangkan lamanya waktu yang dipelajari adalah $8,10,12$, dan 14 jam dengan suhu $60^{\circ} \mathrm{C}$. Karakterisasi kitosan yang diperoleh dengan suhu 60,70 , dan $80^{\circ} \mathrm{C}$ telah menghasilkan kitosan yang sesuai dengan standar mutu kitosan, sedangkan variasi waktu yang menghasilkan kitosan yang paling baik ialah pada waktu deasetilasi 8 jam. Uji kelarutan kitosan yang dilakukan dalam asam asetat $2 \%$ menunjukkan bahwa kelarutan semakin meningkat dengan peningkatan suhu. Berbeda dari perlakuan variasi waktu, kelarutan kitosan semakin menurun dengan proses deasetilasi yang semakin lama. Derajat deasetilasi menunjukkan hasil kemurnian kitosan dengan perlakuan pada variasi suhu $80^{\circ} \mathrm{C}$ menghasilkan kitosan terbaik dan memenuhi standar mutu kitosan, yaitu sebesar $75,98 \%$. Sementara itu, derajat deasetilasi yang paling tinggi diperoleh pada waktu deasetilasi 8 jam, yaitu sebesar $71,12 \%$.
\end{abstract}

Kata kunci: derajat deasetilasi, exuviae BSF, kitosan

\section{ABSTRACT}

As Black Soldier Fly farming has become an emerging trend in Indonesia there is a new opportunity to take advantage from the waste generated from the activity. One of them is the exuviae, which is resulted from the emergence of the fly and it has a high chitin content. Chitin from BSF exuviae have low Cristalinity Indexes. Hence, it shows a promising potential to be processed to produce a new biopolimer. Therefore, converting chitin from BSF exuviae into chitosan using deacetylation process was studied. The researched variables were temperature and the duration of the process, which were studied at $50,60,70$, and $80^{\circ} \mathrm{C}$ for 12 hours and $8,10,12$, and 14 hours at $60^{\circ} \mathrm{C}$, respectively. Chitosan produced in the temperature of 60,70 , and $80^{\circ} \mathrm{C}$ has met the standard quality, and the best duration of deacetylation process was 8 hours. The solubility test in acetic acid $(2 \%)$ showed that chitosan solubility was increased with the increase of temperature, while it decreased as the duration of the process becomes longer. Moreover, the degree of deacetylation showed that chitosan was produced with the best quality in $80^{\circ} \mathrm{C}$ of temperature $(75.98 \%)$ and 8 hours of deacetylation process $(71.12 \%)$.

Keywords: chitosan, degrees of deacetylation, exuviae of black soldier fly

\section{PENDAHULUAN}

Budi daya Hermetia illucens (Black Soldier Fly, BSF) semakin menjamur belakangan ini di Indonesia. Hal ini disebabkan karena fase belatung dari BSF diketahui memiliki kadar protein yang tinggi (mencapai $40 \%$ ) sehingga banyak dibudidayakan sebagai bahan baku protein alternatif. Budi daya Hermetia illucens

\footnotetext{
1 Pusat Penelitian Bioteknologi dan Bioindustri Indonesia, JI. Taman Kencana No. 01, Bogor 16128

2 Departemen Biokimia, Fakultas Matematika dan IImu Pengetahuan Alam, Institut Pertanian Bogor, Kampus IPB Darmaga, Bogor 16680

* Penulis Korespondensi: Email: sri09wahyuni@gmail.com
}

Dalam budi daya BSF menghasilkan limbah berupa selongsong BSF (exuviae) yang belum banyak termanfaatkan, sekitar 2/5 dari total produksi, atau sekitar $400 \mathrm{~kg} / \mathrm{hari}$. Exuviae dihasilkan pada saat pupa berganti kulit ke tahap instar berikutnya. Hingga saat ini, exuviae ini belum dimanfaatkan sama sekali.

Exuviase berpotensi menjadi bahan baku alternatif dalam produksi kitosan. Wasko et al. (2016) melaporkan bahwa kitin yang diekstrak dari $H$. Illucens mempunyai sifat fisikokimia yang berbeda dibandingkan dengan kitin lain yang pernah ditemukan sebelumnya. Kitin yang diekstrak dari exuviae $H$. Illucens memiliki Crystallinity Indexes yang rendah, yaitu sebesar $24,9 \%$ untuk lalat dewasa dan 35\% untuk larva. Sifat kitin ini sangat cocok dimanfaatkan sebagai 
bahan biosorption karena kitin dengan indeks $\mathrm{Crl}$ yg rendah memiliki sorptive capacity yang tinggi. Dengan demikian, $H$. illucens ini merupakan sumber baru biopolimer kitin yang menarik untuk diteliti dan digunakan dalam berbagai aplikasi biokimia, khususnya biosorption.

Dalam proses produksi kitin, dilakukan melalui 3 tahap yang meliputi proses demineralisasi, deproteinasi, dan deasetilasi. Proses deasetilasi merupakan proses terpenting dari 2 proses lainnya karena sangat menentukan kualitas kitosan yang dihasilkan. Faktorfaktor utama yang menentukan keberhasilan proses deasetilasi adalah suhu dan waktu ekstraksi (Siregar et al. 2016). Oleh karena itu, penelitian ini dilakukan untuk mengetahui optimasi produksi kitin dan kitosan berbasis exuviae dari $H$. Illucens dengan variasi waktu dan suhu proses.

\section{METODE PENELITIAN}

Penelitian dilaksanakan di Laboratorium Biokimia, Pusat Penelitian Bioteknologi dan Bioindustri Indonesia pada tahun 2019. Selongsong limbah H.llucens (exuviae) diperoleh dari PT. Biomagg Indonesia-Depok.

\section{Alat dan Bahan}

Alat yang digunakan pada penelitian meliputi gelas piala $2000 \mathrm{~mL}$, gelas piala $600 \mathrm{~mL}$, gelas piala $500 \mathrm{~mL}$, gelas piala $250 \mathrm{~mL}$, gelas piala kecil, labu takar 100 $\mathrm{mL}$, gelas ukur $5000 \mathrm{~mL}$, gelas ukur $2000 \mathrm{~mL}$, gelas ukur $1500 \mathrm{~mL}$, gelas ukur $500 \mathrm{~mL}$, neraca analitik, timbangan $10 \mathrm{~kg}$, spatula, gelas arloji, cawan petri, batang pengaduk, magnetic stirrer, stirrer, termometer, pipet volumetrik $25 \mathrm{~mL}$, pipet volumetrik $5 \mathrm{~mL}$, pipet volumetrik $2 \mathrm{~mL}$, pipet volumetrik $1 \mathrm{~mL}$, pipet mohr 50 $\mathrm{mL}$, hotplate, oven, saringan, tabung reaksi, beker glass $500 \mathrm{~mL}$, blender, penjepit kayu, pisau, corong (pyrex), vakum, dan wadah khusus ekstraksi kitin. Bahan yang digunakan pada penelitian ini adalah selongsong pupa BSF $5000 \mathrm{~g}, \mathrm{NaOH} 2 \mathrm{M}, \mathrm{HCl} 3 \mathrm{M}$, air suling, asam asetat glasial $98 \%, \mathrm{KMNO}_{4} 2 \%$, asam oksalat $2 \%$, akudes.

\section{Proses Ekstraksi Kitin dan Kitosan}

Proses ekstraksi kitosan dari exuviae terdiri atas 4 tahap, yaitu demineralisasi, deproteinasi, depigmentasi, dan deasetilasi. Proses demineralisasi dilakukan menggunakan larutan $\mathrm{HCl} 3 \mathrm{M}$ dengan perbandingan $1: 10$. Proses deproteinasi dilakukan menggunakan $\mathrm{NaOH} 2 \mathrm{M}$ dengan perbandingan 1:10. Proses depigmentasi atau penghilangan pigmen dilakukan melalui perendaman dalam $100 \mathrm{~mL}$ larutan $\mathrm{KMnO}_{4} 1 \%$ dilanjutkan dengan perendaman $100 \mathrm{~mL}$ asam oksalat $1 \%$. Setelah dilakukan ekstraksi kitin, kemudian kitin yang didapatkan dicuci sampai netral dan dikeringkan.
Tahap terakhir adalah deasetilasi dengan menggunakan $\mathrm{NaOH}$ 50\%. Optimasi proses deasetilasi kitin mejadi kitosan dilakukan dengan menimbang sebanyak $2 \mathrm{~g}$ kitin kemudian dimasukkan ke dalam gelas piala yang berisi $60 \mathrm{~mL}$ larutan $\mathrm{NaOH} 50 \%(w / v)$ dan diaduk sampai kitin terendam sempurna. Pengadukan dilanjutkan dengan menggunakan magnetic stirrer yang diaduk di atas hot plate menggunakan suhu dan waktu tertentu. Optimasi suhu dilakukan pada variasi suhu deasetilasi $50,60,70$, dan $80^{\circ} \mathrm{C}$ selama 12 jam. Sementara itu, optimasi waktu ekstraksi dilakukan dengan menggunakan suhu $60^{\circ} \mathrm{C}$ pada variasi waktu $8,10,12$, dan 14 jam. Masing-maing variasi deasetilasi dilakukan secara triplo.

\section{Karakterisasi Kitosan}

Karakterisasi kitosan meliputi analisis fisik, rendemen, uji kelarutan, dan perhitungan derajat deasetilasi. Karakterisasi kitosan meliputi analisis fisik kitosan berupa warna dan tekstur kitosan yang dihasilkan. Menurut Kurniawati (2010), warna kitin dan kitosan yang digunakan sebagai standar adalah warna kitin dan kitosan udang, yaitu putih kekuningan. Rendemen kitosan dihitung dengan menggunakan rumus yang sama dengan penghitungan rendemen kitin. Kemudian, uji kelarutan kitosan dilakukan melalui perendaman $0,2 \mathrm{~g}$ kitosan dalam $20 \mathrm{~mL}$ asam asetat $2 \%$. Kitosan yang telah terbentuk kemudian ditimbang untuk menghitung rendemen yang dihasilkan dengan menggunakan rumus berikut:

$$
\% \text { Rendemen }=\frac{\text { Massa kitosan }}{\text { Massa selongsong kering }} \times 100 \%
$$

Penentuan derajat deasetilasi (DD) dilakukan dengan analisis Spektrum FTIR (Kanto et al. 2019). Metode kuantitatif menggunakan spektrofotometri infra merah dilakukan berdasarkan nilai transmitansi (\%) atau absorbansi. Perhitungan derajat deasetilasi (\% DD) dari spektra infra merah pada kitosan dapat dilakukan dengan cara dihitung perbandingan absorbansi bilangan gelombang gugus amida-NH (A 1655) dengan absorbansi bilangan gelombang gugus amina primer (A 3450), dengan nilai absorbansi 1,33 pada proses deasetilasi sempurna. Perhitungan derajat deasetilasi dihitung berdasarkan rumus sebagai berikut:

$$
\% \text { DD }=1-\left[\frac{A 1655}{A 3450}-\frac{1}{1.33}\right] \times 100 \%
$$

Keterangan:

A1665 = Absorbansi pada bilangan gelombang 1665 $\mathrm{cm}^{-1}$

A3450 = Absorbansi pada bilangan gelombang 3450 $\mathrm{cm}^{-1}$

$1,33=$ Tetapan yang diperoleh dari perbandingan A1665/A3450 untuk kitosan dengan asetilasi penuh 


\section{Analisis Statistik}

Data hasil penelitian dianalisis secara statistik menggunakan metode ANOVA (Uji F) pada taraf uji $5 \%$. Bila terdapat hasil yang berbeda nyata dilanjutkan dengan uji Duncan pada $\alpha=5 \%$.

\section{HASIL DAN PEMBAHASAN}

\section{Ekstraksi Kitin dari Selongsong Pupa BSF}

Proses ekstraksi kitin dilakukan melalui 3 tahapan yang terdiri atas demineralisasi, deproteinasi, dan depigmentasi yang dilakukan dengan menggunakan metode kimiawi (Kanto et al. 2019). Metode kimiawi dilakukan melalui perendaman menggunakan $\mathrm{HCl} 2 \mathrm{M}$ untuk demineralisasi, $\mathrm{NaOH} 3 \mathrm{M}$ untuk deproteinasi, serta $\mathrm{KMnO}_{4}$ dan asam oksalat masing-masing $1 \%$ untuk depigmentasi. Proses demineralisasi dan deproteinasi masing-masing dilakukan dalam waktu 36 jam, proses depigmentasi dilakukan selama 2 jam dengan pengadukan $150 \mathrm{rpm}$. Proses demineralisasi merupakan proses penghilangan mineral yang terdapat di dalam selongsong pupa BSF, umumnya mineral terdapat dalam bentuk kalsium karbonat $\left(\mathrm{CaCO}_{3}\right)$ dan kalsium fosfat $\left(\mathrm{Ca}_{3}\left(\mathrm{PO}_{4}\right)_{2}\right.$ (Mursida et al. 2018).

Proses pemisahan mineral ditunjukkan dengan pembentukan gas $\mathrm{CO}_{2}$ berupa gelembung udara pada saat selongsong pupa dimasukkan ke dalam larutan $\mathrm{HCl}$ (Mursida et al. 2018). Hasil proses demineralisasi yang telah dicuci menjadi lebih lunak karena telah kehilangan kandungan mineral dan protein dan menghasilkan padatan serbuk berwarna hitam sesuai dengan yang disampaikan oleh Younes \& Rianudo (2015). Melalui proses deproteinasi, ion $\mathrm{Na}^{+}$akan mengikat ujung rantai protein yang bermuatan negatif sehingga akan larut dengan pelarut natrium hidroksida (Rochima 2014). Pencucian sampai netral ditujukan agar tidak terjadi perubahan $\mathrm{pH}$ secara ekstrem ketika perpindahan dari larutan $\mathrm{pH}$ yang sangat asam ke larutan yang sangat basa yang dapat menyebabkan kerusakan pada sampel (Sugita et al. 2009).

Proses depigmentasi atau dekolorisasi merupakan salah satu proses yang dapat menentukan keberhasilan deproteinasi karena memengaruhi warna kitosan yang dihasilkan. Penggunaan $\mathrm{KMnO}_{4}$ untuk proses depigmentasi sesuai dengan pernyataan Budiyono (2016) bahwa proses depigmentasi dapat menggunakan reagen oksidator seperti aseton, asam oksalat, kaporit, atau $\mathrm{KMnO}_{4}$ untuk menghilangkan pigmen yang masih terikat pada kitin. Hasil depigmentasi menunjukkan sampel mengalami perubahan warna menjadi putih kekuningan, namun masih terdapat sedikit bercak berwarna hitam yang disebabkan oleh masih adanya pigmen yang belum terangkat, seperti yang terlihat pada Gambar 1.

Setelah didapatkan kitin, kemudian dikeringkan secara alami sampai kering dan kitin ditimbang untuk mengetahui rendemen dari hasil ekstraksi kitin. Hasil ekstraksi menghasilkan kitin sebanyak $58.848 \mathrm{~g}$ dari bobot sampel total, yaitu $500 \mathrm{~g}$ pupa BSF (rendemen kitin sebesar $11,8 \%$ ). Hasil ini lebih kecil dari yang didapatkan oleh Kanto et al. (2019), yaitu sebesar $17,93 \%$ dengan sampel yang diekstraksi adalah lalat dewasa $H$. illucens. Sementara itu, menurut Wang \& Shelomi (2017), kandungan kitin terkoreksi pada larva BSF adalah $2-5 \%$. Berdasarkan hal tersebut dapat diketahui bahwa setiap fase pada BSF memiliki kandungan kitin yang berbeda-beda. Semakin dewasa, maka kandungan kitin semakin banyak.

\section{Karakterisasi Fisik Kitosan}

Produk kitosan yang diperoleh dari deasetilasi kitin pada variasi suhu ekstraksi menghasilkan karakterisasi warna dan penampilan yang disajikan pada Gambar 2, di mana tidak jauh berbeda untuk setiap perlakuan suhu pada tiga kali ulangannya. Perlakuan suhu $50^{\circ} \mathrm{C}$ menghasilkan warna kitosan mendekati putih dari tiga kali ulangan yang dilakukan, sedangkan suhu 60, 70, dan $80^{\circ} \mathrm{C}$ sudah menghasilkan kitosan yang lebih mendekati putih dari tiga kali ulangan yang dilakukan. Karakterisasi penampilan fisik kitosan yang dihasilkan untuk setiap perlakuan suhu juga tidak jauh berbeda di mana perlakuan suhu $50^{\circ} \mathrm{C}$ dan $60^{\circ} \mathrm{C}$ mengasilkan kitosan dengan bentuk kepingan serbuk dengan tekstur yang sedikit kasar, sedangkan perlakuan suhu $70^{\circ} \mathrm{C}$ menghasilkan kitosan dengan bentuk kepingan serbuk dengan tekstur yang lebih halus. Begitu juga suhu $80^{\circ} \mathrm{C}$ menghasilkan kitosan bentuk kepingan serbuk serta tekstur yang halus. Hasil percobaan ini sesuai dengan pernyataan Melati (2014) yang

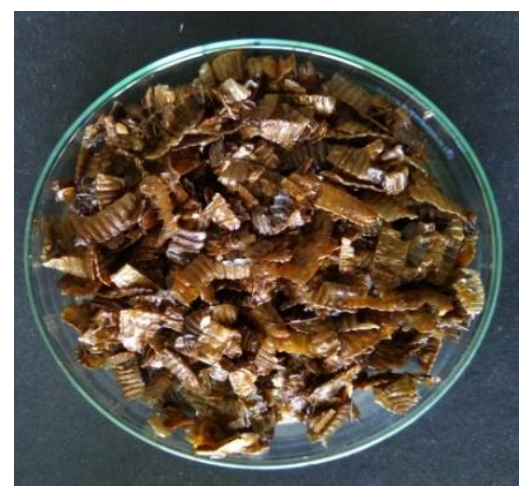

a

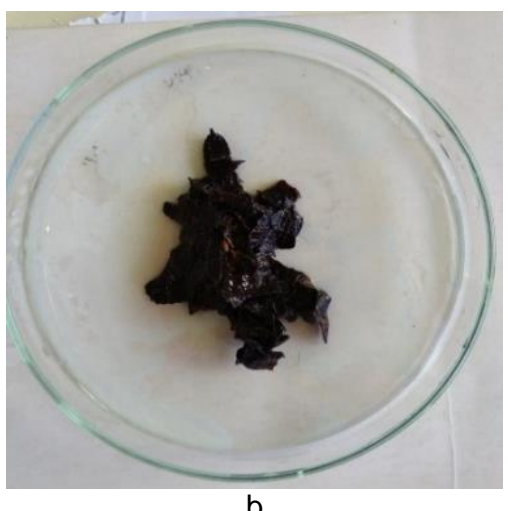

b

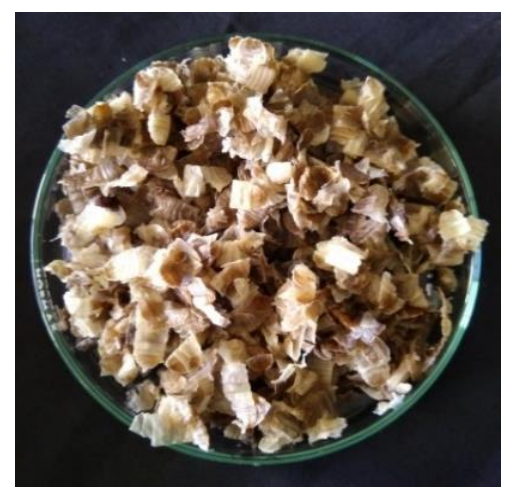

C

Gambar 1 Ekstraksi kitin. a) Demineralisasi dan deproteinasi, b) Perendaman $\mathrm{KMnO}_{4}$, dan c) Depigmentasi. 


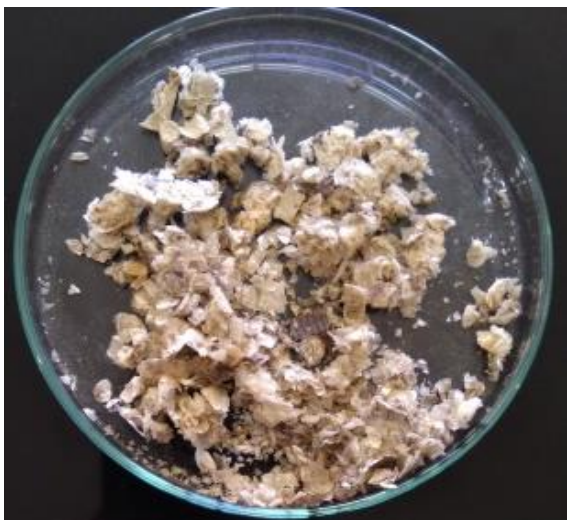

a

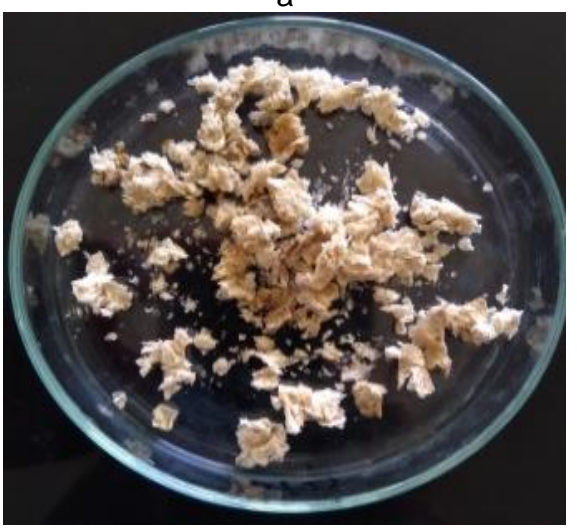

C

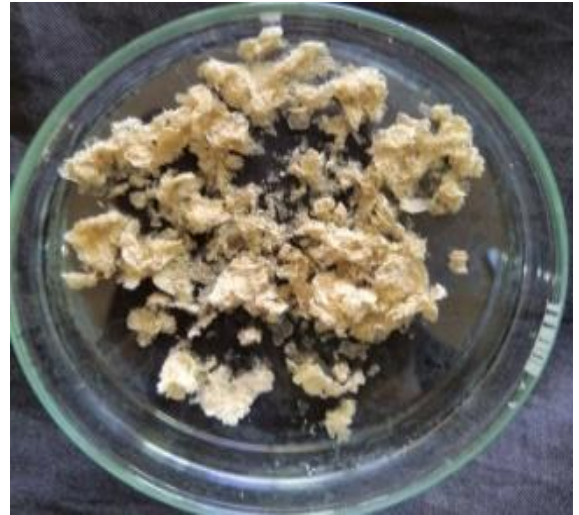

b

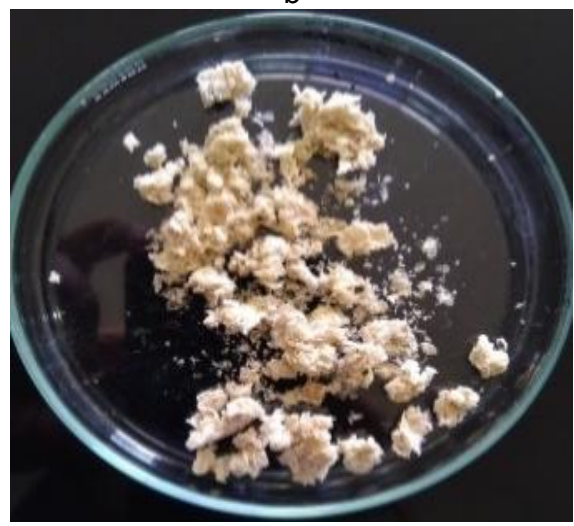

d

Gambar 2 Hasil karakterisasi kitosan perlakuan variasi suhu a) $50^{\circ} \mathrm{C}$, b) $60^{\circ} \mathrm{C}$, c) $70^{\circ} \mathrm{C}$, dan d) $80^{\circ} \mathrm{C}$ selama 12 jam.

menyatakan bahwa suhu berpengaruh pada warna dan penampilan fisik kitosan di mana semakin tinggi suhu maka warna kitosan akan cenderung lebih putih dan penampilan fisiknya akan semakin mendekati serbuk.

Sementara itu, karakteristik kitosan dengan variasi waktu ditampilkan pada Gambar 3. Kitosan yang dihasilkan dari deasetilasi variasi waktu selama 8 jam memiliki warna putih kekuningan dengan tekstur kasar dan hancur berbentuk serbuk yang membentuk gumpalan kecil dan tidak berbau. Warna yang berbeda muncul pada kitosan deasetilasi selama 10 jam, di mana kitosan yang dihasilkan berwarna cokelat seulas atau lebih gelap dari kitosan hasil deasetilasi 8 jam. Tekstur yang dihasilkan lebih hancur dan hanya sedikit menggumpal dengan tekstur yang kasar. Hampir serupa dengan hasil deasetilasi 10 jam, kitosan dengan hasil deasetilasi 12 jam juga menunjukkan warna putih cokelat seulas dengan bentuk yang hancur berbentuk serbuk dengan sedikit menggumpal dan tekstur yang kasar. Sementara itu, deasetilasi kitin selama 14 jam menghasilkan kitosan dengan warna putih kekuningan, seperti hasil deasetilasi 8 jam dengan tekstur kasar sedikit hancur dan beberapa kitin masih dapat dikenali bentuknya. Hasil karakterisasi produk kitosan yang diperoleh, baik pada variasi suhu maupun waktu ekstraksi, sudah sesuai dengan BSN (2013), yakni memilki warna putih yang cenderung kekuningan dengan tekstur berupa serbuk yang halus.

\section{Rendemen Kitosan}

Pembuatan kitosan melalui proses deasetilasi dengan menggunakan $\mathrm{NaOH} 50 \%$ ditujukan untuk memutus ikatan antara karbon pada gugus asetil dengan atom nitrogen pada kitin sehingga berubah menjadi gugus amina (- $\left.\mathrm{NH}_{2}-\right)$. Konsentrasi $\mathrm{NaOH} 50 \%$ dipilih selain berdasarkan hasil percobaan yang sebelumnya dilakukan, namun juga dianggap lebih ekonomis dan ramah lingkungan dibanding dengan konsentrasi yang lebih tinggi. Selain itu, penggunaan konsentrasi yang lebih tinggi sangat dihindari karena semakin besar konsentrasi basa yang digunakan untuk deasetilasi akan meningkatkan kemungkinan terjadinya tumbukan dalam reaksi deasetilasi (Azhar et al. 2010).

Kitin memiliki sifat yang tahan terhadap larutan basa konsentrasi tinggi karena memiliki unit yang berstruktur kristalin dan adanya ikatan hidrogen yang meluas antaratom nitrogen dan gugus karboksil (Savitri et al. 2010). Hasil pengamatan menunjukkan bahkan ekstraksi pada suhu $60^{\circ} \mathrm{C}$ menghasilkan rendemen terbesar $(5,78 \%)$ yang secara signifikan berbeda nyata dibandingkan dengan perlakuan lain, namun tidak berbeda nyata dibandingkan dengan variasi suhu $50^{\circ} \mathrm{C}$. Berdasarkan Gambar 4 dapat dilihat hasil ratarata berat kitosan yang diperoleh dari optimasi proses deasetilasi dengan variasi suhu $50,60,70$, dan $80^{\circ} \mathrm{C}$ selama 12 jam mengalami penurunan. Hal ini sesuai dengan pernyataan Priyambodo (2009) bahwa kitosan diperoleh melalui proses demineralisasi, deproteinasi, 


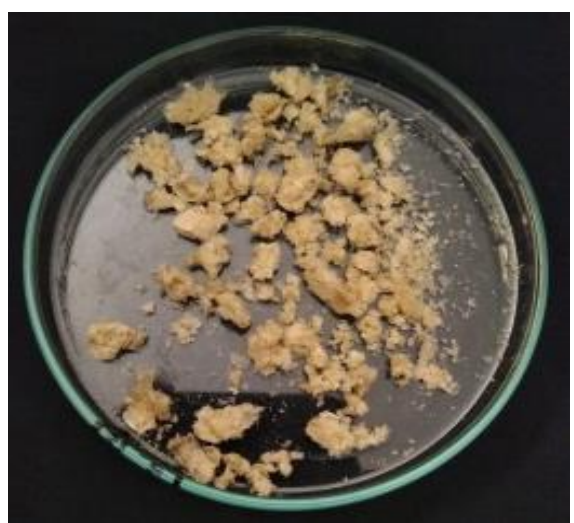

a

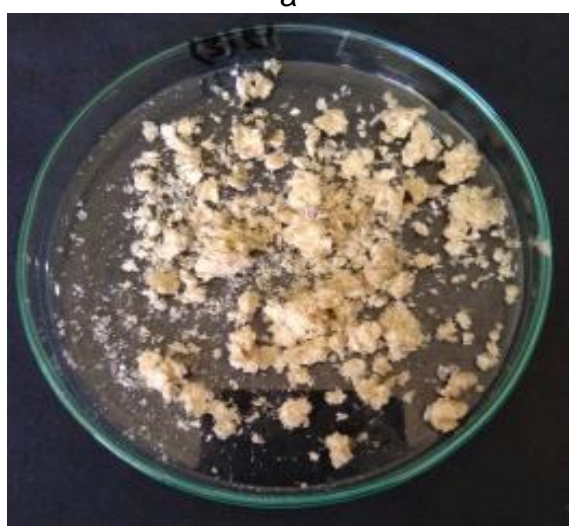

C

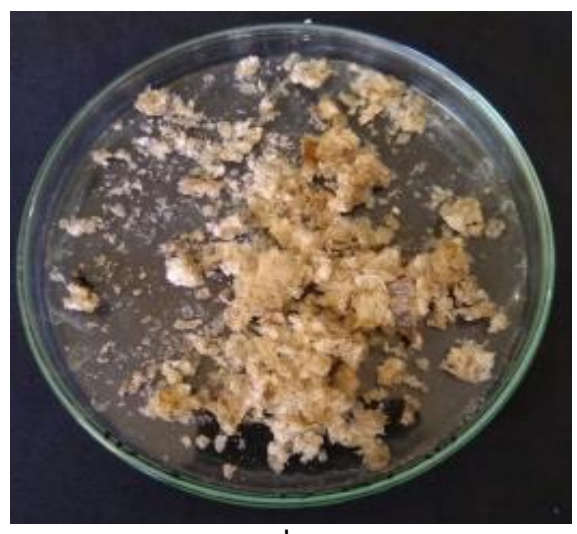

$\mathrm{b}$

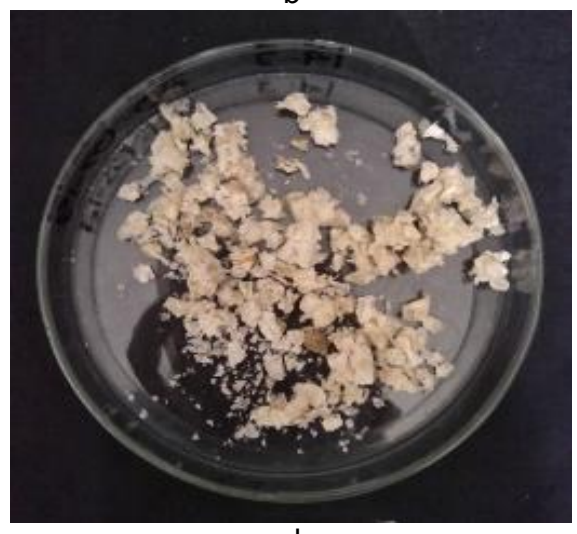

d

Gambar 3 Hasil karakterisasi kitosan perlakuan variasi waktu a) 8 jam, b) 10 jam, c) 12 jam, dan d) 14 jam.

dan deasetilasi mengakibatkan komponen mineral atau bahan organik lainnya dan protein pada bahan baku selongsong pupa maggot terlarut dalam larutan $\mathrm{HCl}$ maupun $\mathrm{NaOH}$ sehingga mengakibatkan bobot akhir kitosan lebih rendah dibandingkan dengan bobot bahan baku awal (selongsong pupa maggot). Rata-rata bobot kitosan paling tinggi didapat pada suhu deasetilasi $60^{\circ} \mathrm{C}$, yaitu sebesar $1,0407 \mathrm{~g}$ atau dengan rendemen $5,78 \%$, sedangkan paling rendah didapat pada suhu deasetilasi $80^{\circ} \mathrm{C}$ sebesar $0,5593 \mathrm{~g}$ dengan rendemen $3,11 \%$.

Berbeda dari perlakuan variasi suhu, hasil deasetilasi dengan variasi waktu (Gambar 5) menunjukkan bahwa deasetilasi dengan waktu 10 jam menghasilkan bobot kitosan yang paling sedikit, yaitu 0,7584 g dengan rendemen $4,21 \%$ dan hasil kitosan terbanyak adalah pada waktu deasetilasi 12 jam, yaitu $0,8744 \mathrm{~g}$ atau 4,86\%. Wahyuni et al. (2016) menyatakan bahwa semakin lama waktu yang digunakan dalam proses deasetilasi maka rendemen kitosan yang dihasilkan semakain sedikit. Hal ini tidak sesuai dengan hasil yang didapatkan dalam penelitian di mana lamanya waktu proses deasetilasi tidak menunjukkan pengaruh yang nyata pada kitosan yang dihasilkan. Hal ini terjadi karena proses deasetilasi yang tidak sempurna sehingga banyak gugus asetil pada kitin yang tidak tereduksi dan menghasilkan bobot yang tinggi (Wahyuni et al. 2016). Proses deasetilasi yang tidak sempurna dapat terjadi karena pengadukan yang tidak sempurna.

\section{Kelarutan Kitosan}

Kelarutan kitosan dalam asam asetat merupakan salah satu parameter standar mutu kitosan. Semakin tinggi kelarutan kitosan dalam asam asetat $2 \%$ berarti mutu kitosan yang dihasilkan semakin baik (Agustina et al. 2015). Kelarutan diamati dengan membandingkan kejernihan larutan kitosan dengan kejernihan pelarutnya. Kelarutan diamati dengan melarutkan 0,2 g kitosan di dalam $20 \mathrm{~mL}$ asam asetat $2 \%$, kemudian larutan diamati dengan membandingkan kejernihan larutan kitosan dengan kejernihan pelarutnya. Kemampuan kitosan yang hanya dapat larut dalam asam encer seperti asam asetat karena terjadinya interaksi hidrogen antara gugus karboksil pada asam asetat dengan amina dari kitosan (Dompeipen et al. 2016).

Berdasarkan hasil uji kelarutan yang disajikan pada Gambar 6 dapat dilihat bahwa kelarutan paling tinggi terdapat pada perlakuan suhu $80^{\circ} \mathrm{C}$, yaitu sebesar $87,95 \%$, sedangkan kelarutan paling rendah, yaitu $6,59 \%$ ditemukan pada suhu $50^{\circ} \mathrm{C}$. Hasil pengujian menunjukkan bahwa variasi suhu secara signifikan berpengaruh pada tingkat kelarutan kitosan dalam larutan asam asetat $2 \%$. Semakin tinggi suhu maka semakin tinggi pula tingkat kelarutan. Hasil percobaan ini sesuai dengan hasil Budiutami et al. (2012) yang menyatakan bahwa suhu tinggi sangat memengaruhi proses depolimerisasi/degradasi kitin. Kelarutan dalam asam asetat tertinggi adalah kitosan dengan waktu deasetilasi 8 jam, sementara itu kelarutan terendah adalah kitosan hasil deasetilasi 14 jam. Hasil penelitian 


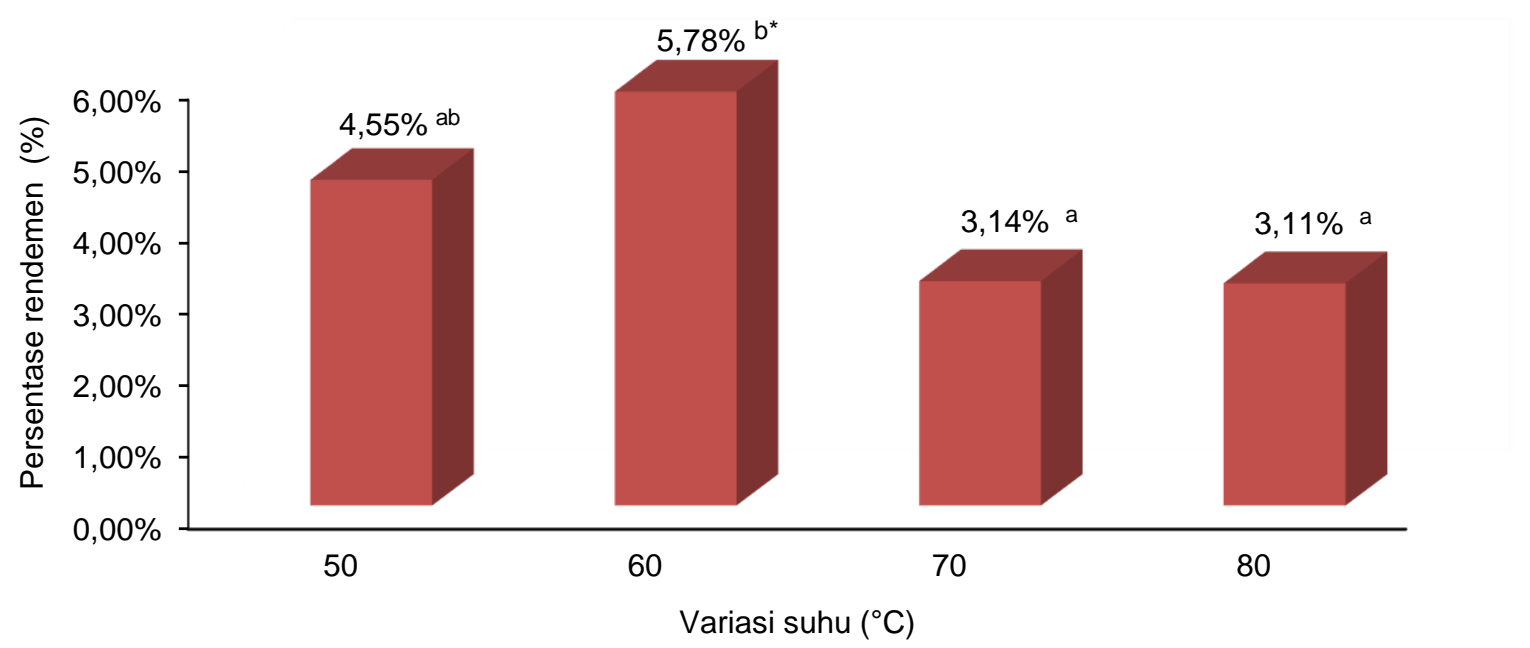

Gambar 4 Grafik perubahan rendemen kitosan pada variasi suhu dengan. Angka yang diikuti oleh huruf yang sama berarti tidak berbeda nyata menurut uji Duncan pada $\alpha=5 \%$.

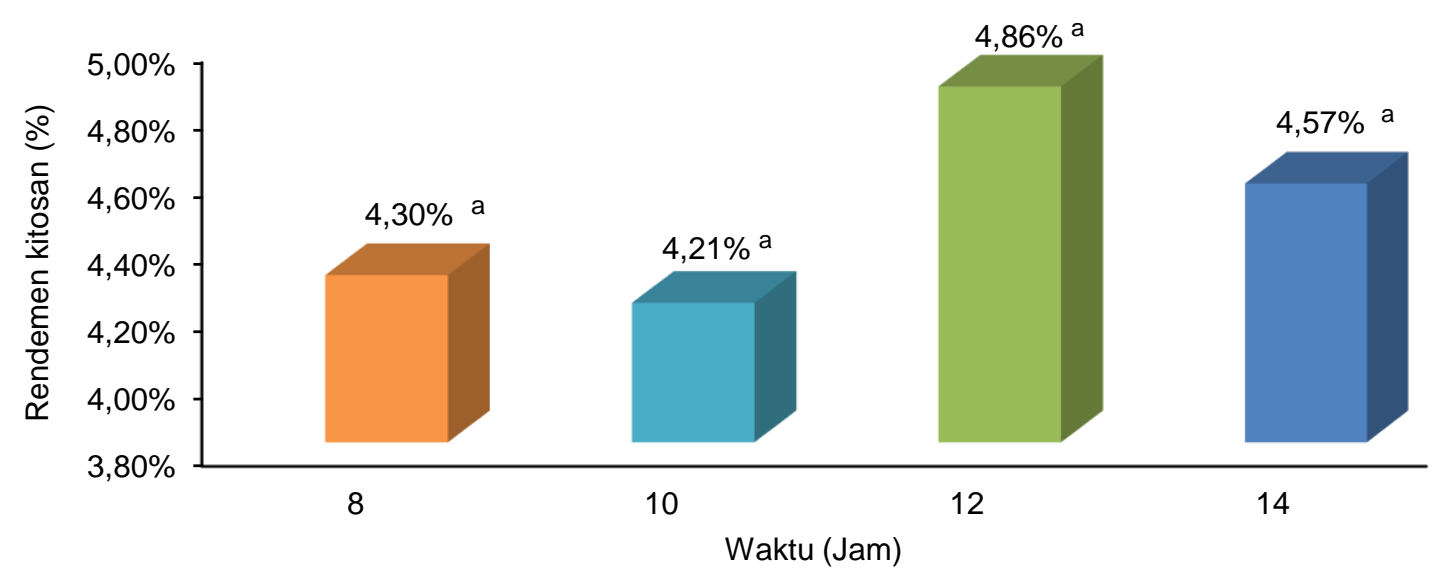

Gambar 5 Grafik perubahan rendemen kitosan pada variasi waktu. Angka yang diikuti oleh huruf yang sama berarti tidak berbeda nyata menurut uji Duncan pada $\alpha=5 \%$.

pada Gambar 7 menunjukkan bahwa semakin lama proses deasetilasi, kelarutan kitosan dalam asam asetat semakin menurun. Hasil pengujian menunjukkan bahwa waktu ekstraksi 8 dan 10 jam menghasilkan rendemen terbesar dan secara signifikan berbeda dari perlakuan 12 dan 14 jam. Menurut Dompeipen et al. (2016) bahwa semakin tinggi kelarutan kitosan dalam asam asetat $2 \%$ menunjukkan bahwa mutu kitosan yang dihasilkan semakin baik.

\section{Derajat Deasetilasi Kitosan}

Derajat deasetilasi menunjukkan tingkat keberhasilan proses deasetilasi. Hasil pengukuran derajat deasetilasi dengan variasi suhu ditunjukkan pada Gambar 8. Kitosan dengan perlakuan suhu $80^{\circ} \mathrm{C}$ memilki derajat deasetilasi paling tinggi, yaitu sebesar $75,98 \%$, diikuti oleh suhu $70^{\circ} \mathrm{C}$ sebesar $73,52 \%, 60{ }^{\circ} \mathrm{C}$ sebesar $70,49 \%$, dan suhu $50^{\circ} \mathrm{C}$ sebesar $62,72 \%$. Berdasarkan Gambar 9, spectrum FTIR menunjukkan derajat deasetilasi yang semakin meningkat dengan peningkatan suhu. Hal ini sesuai dengan penelitian
Siregar et al. (2016) yang menyatakan bahwa suhu, waktu, ukuran partikel, dan konsentrasi berpengaruh pada derajat deasetilasi di mana semakin meningkat suhu maka semakin banyak gugus asetil yang terlepas dari kitin sehingga meningkatkan derajat deasetilasi kitosan yang dihasilkan. Pada temperatur rendah, reaksi akan berjalan lambat, sedangkan jika temperatur terlalu tinggi dapat merusak struktur bahan dasar.

Hasil optimasi deasetilasi kitosan pada perlakuan suhu $80^{\circ} \mathrm{C}$ telah memenuhi standar derajat deasetilasi kitosan, yaitu minimal $75 \%$ (BSN 2013). Sementara itu, optimasi perlakuan suhu $70^{\circ} \mathrm{C}, 60^{\circ} \mathrm{C}$, dan $50^{\circ} \mathrm{C}$ baru mendekati standar mutu derajat deasetilasi kitosan menurut BSN (2013). Sementara itu, hasil pengukuran derajat deasetilasi kitosan yang diperoleh dengan variasi waktu (Gambar 9), menunjukkan kitosan dengan waktu 8 jam memiliki derajat deasetilasi $71,12 \%, 10$ jam memiliki derajat deasetilasi sebesar $69,21 \%$, derajat deasetilasi kitosan 12 jam adalah $68,56 \%$, dan derajat deasetilasi kitosan 14 jam adalah 


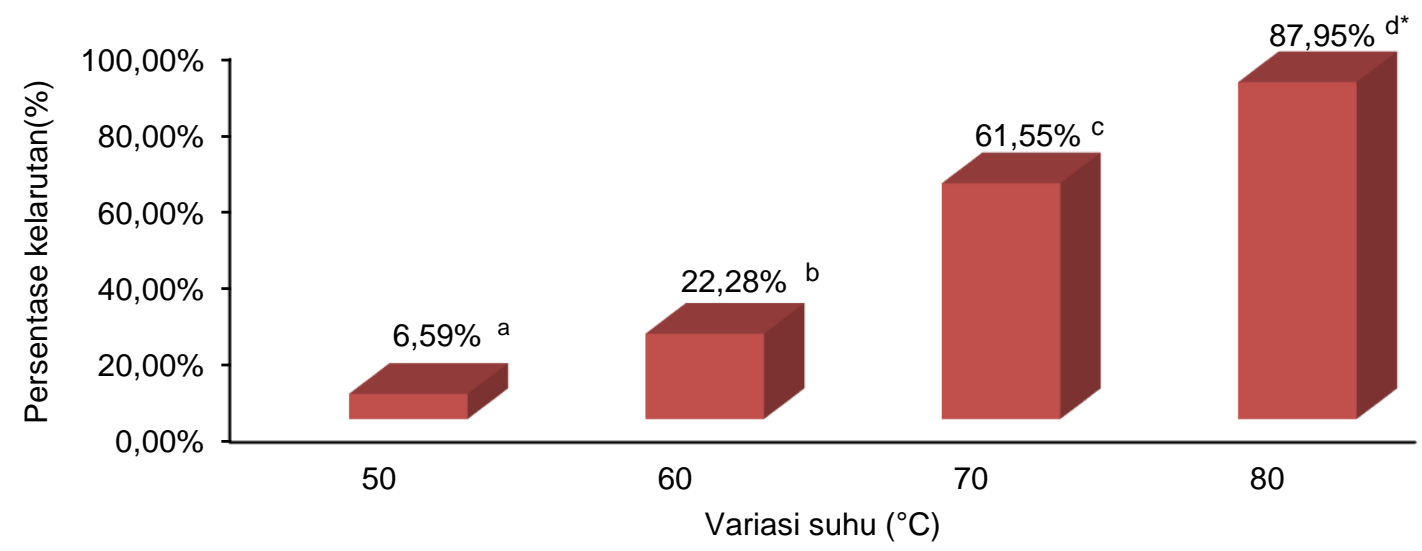

Gambar 6 Grafik perubahan kelarutan kitosan dalam asam asetat 2\% pada variasi suhu dengan waktu 12 jam. Angka yang diikuti oleh huruf yang sama berarti tidak berbeda nyata menurut uji Duncan pada $\alpha=5 \%$.

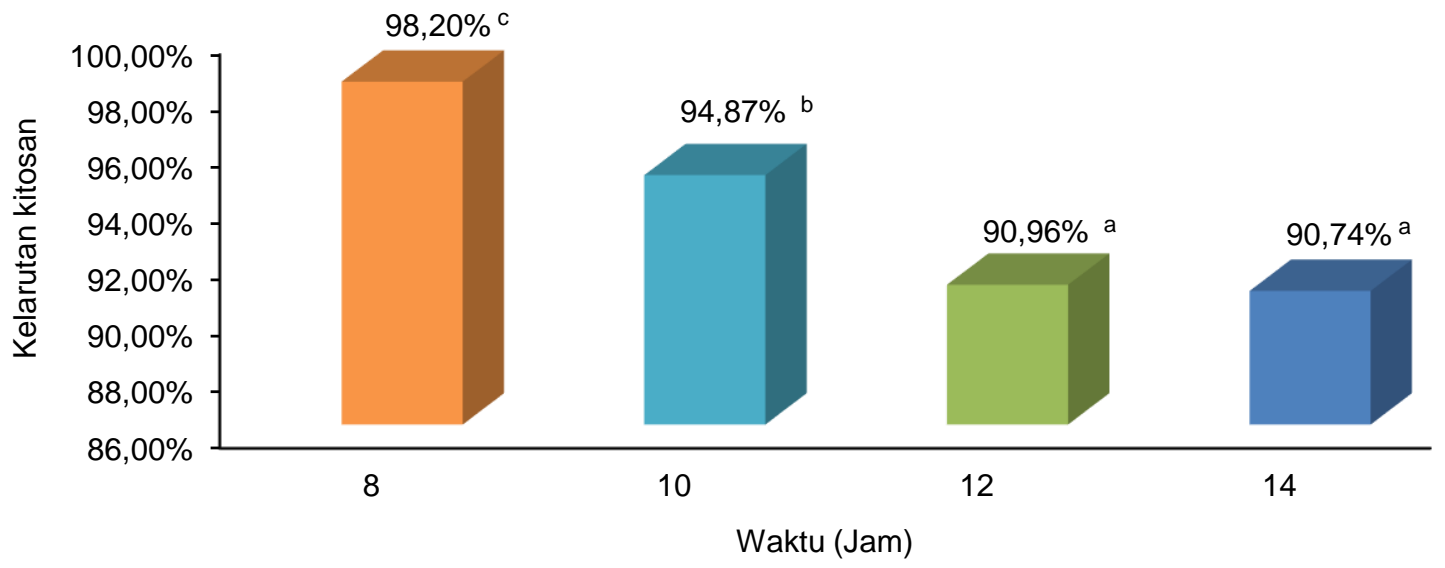

Gambar 7 Grafik perubahan kelarutan kitosan dalam asam asetat 2\% pada variasi waktu. Angka yang diikuti oleh huruf yang sama berarti tidak berbeda nyata menurut uji Duncan pada $\alpha=5 \%$.

68,52\%. Hasil pengukuran derajat deasetilasi menunjukkan bahwa semakin lama proses deasetilasi, mengakibatkan derajat deasetilasi semakin menurun.

\section{KESIMPULAN}

Suhu dan waktu reaksi berpengaruh pada derajat deasetilasi. Semakin tinggi suhu dan lamanya waktu reaksi maka nilai derajat deasetilasi semakin meningkat. Optimasi proses deasetilasi kitosan dengan perlakuan variasi suhu diperoleh kitosan terbaik pada suhu $80^{\circ} \mathrm{C}$. Hasil kitosan yang diperoleh memilki mutu yang bagus dilihat dari warna yang mendekati putih, kelarutan sebesar $87,95 \%$ dan derajat deasetilasi kitosan sebesar $75,98 \%$. Sementara itu, untuk optimasi kitosan dengan perlakuan variasi waktu deasetiasi tidak berpengaruh signifikan pada rendemen kitosan namun melalui uji kelarutan didapatkan bahwa pada waktu deasetilasi 8 jam menghasilkan kelarutan yang paling baik.

\section{DAFTAR PUSTAKA}

Agustina S, Swantara I, Suartha N. 2015. Isolasi kitin, karakterisasi, dan sintesis kitosan dari kulit udang. Journal of Chemistry. 9(2): 90-101.

Azhar M, Efendi J, Syofyeni E, Lesi RM, Novalina S. 2010. Pengaruh konsentrasi $\mathrm{NaOH}$ dan $\mathrm{KOH}$ terhadap derajat deasetilasi kitin dari kulit udang. Eksakta. 1(11): 1-8.

[BSN] Badan Standarisasi Nasional. 2013. KitosanSyarat Mutu dan Pengelolaan SNI 7949-2013. Jakarta (ID): BSN. 


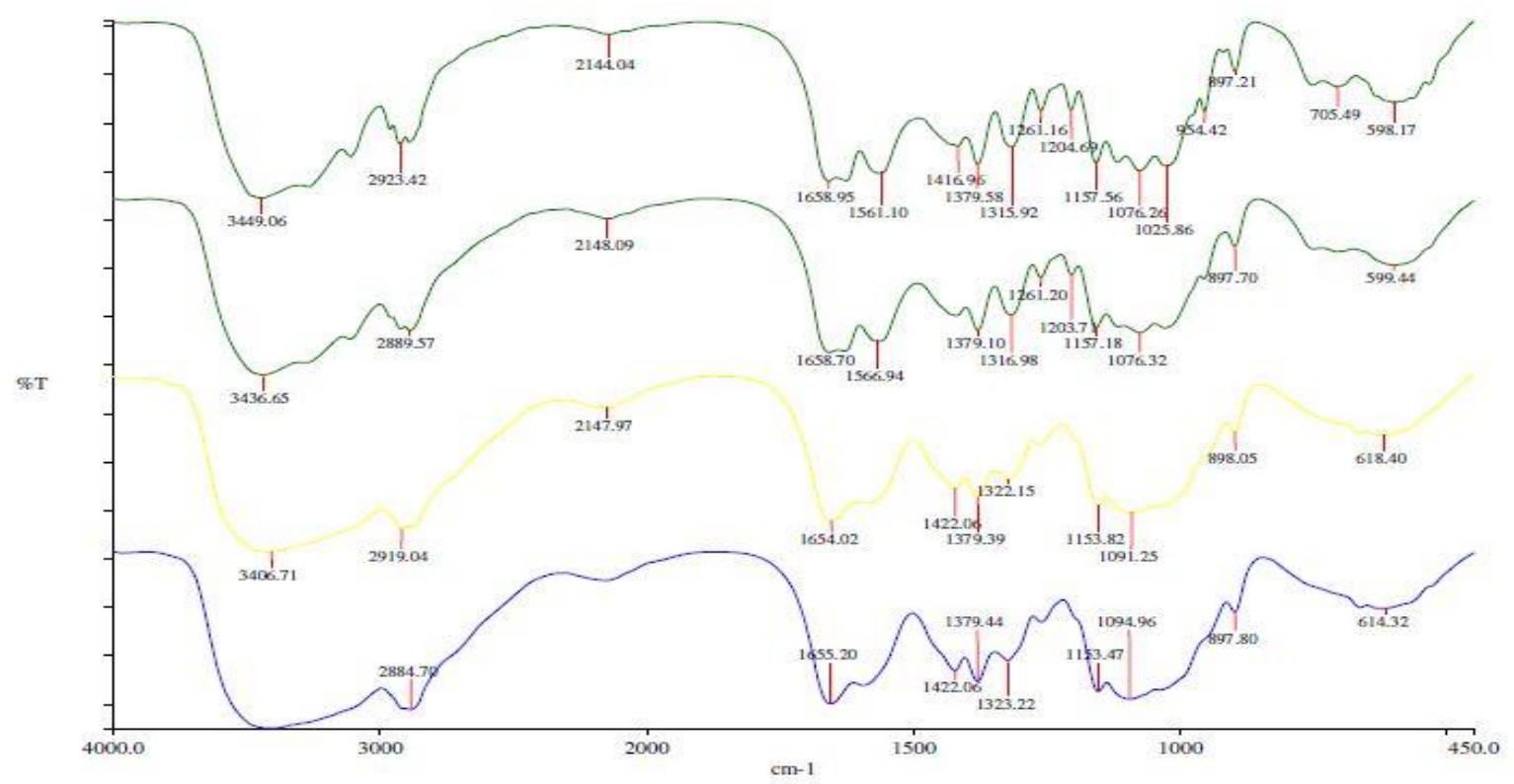

Gambar 8 Hasil pengukuran FTIR kitosan pada variasi suhu $50,60,70$, dan $80^{\circ} \mathrm{C}$ (dari atas ke bawah).

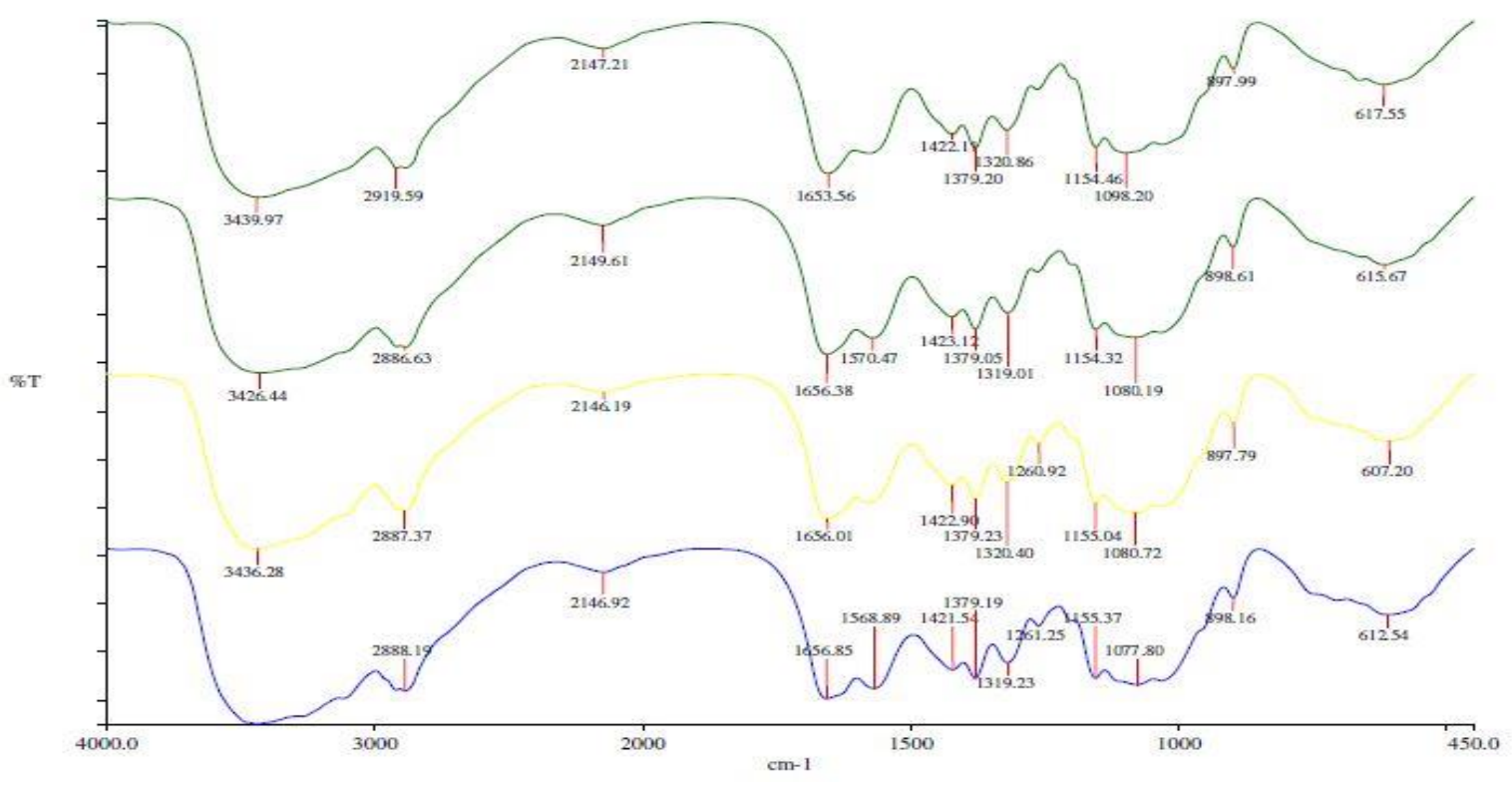

Gambar 9 Hasil pengukuran FTIR kitosan pada variasi waktu (8, 10, 12, dan 14 jam (dari atas ke bawah).

Budiyono A. 2016. Karakterisasi Kitin dan Kitosan asal Kulit Pupa Ulat Sutera Liar (Attacus Atlas L.) dari Perkebunan Teh Walini Purwakarta. [Skripsi]. Bogor (ID): Institut Pertanian Bogor.

Budiutami A, Sari NK, Priyamto S. 2012. Optimasi proses ektraksi kitin menjadi kitosan dari limbah kulit ulat hongkong. Jurnal Teknik Kimia. 1(1): 46-53

Dompeipen J, Edward, Kaimudin, Marni, Dea PR. 2016. Isolasi kitin dan kitosan dari limbah kulit udang. Jurnal Kementerian Perindustrian. 12(1): 32-38.

Kanto DAR, Permana AD, Hertadi R. 2016. Extraction and characterization of kitin and chitosan from black soldier fly (Hermetia illucens). Jurnal IImiah Farmako Bahari. 10(1): 23-32.

Kanto DAR, Permana AD, Hertadi R. 2019. Marine Nutraceutical and Functional Foods: Glucosamine Production and Health Benefits. Canada (USA): CRC Press. https://doi.org/10.1201/978142001 5812.ch8 
Kurniawati FA. 2010. Potensi kitosan dari ulat tepung (Tenebrio molitor L.) pada tingkat umur yang berbeda. [skripsi]. Bogor(ID): Fakultas Peternakan, Institut Pertanian Bogor.

Melati E. 2014. Pembuatan Glukosamin Hidroklorida (Glcn $\mathrm{Hcl}$ ) Dari Kitin Karapas Udang Dengan Metode Autoklaf. [Skripsi]. Bogor (ID): Institut Pertanian Bogor.

Mursida, Sahriawati dan Tasir. 2018. Efektifitas alkali pada proses deasetilasi dari berbagai bahan baku kitosa. Jurnal Pengolahan Hasil Perikanan Indonesia. 21(2): 356-366. https://doi.org/10. 17844/jphpi.v21i2.23091

Pamungkas T, Sumardiyono C, Pusposendjojo N. 2007. Extraction, characterization and inhibition test of natural chitosan to colletotrichum musae in vitro. Journal of Chemical Process Engineering. 15(1): 39-44.

Priyambodo E. 2009. Pengaruh Konsentrasi Kitosan dari Cangkang Udang Terhadap Efesiensi Penjerapan Logam Berat. [skripsi]. Yogyakarta (ID): Fakultas matematika dan IImu Pengetahuan Alam. Universitas Negeri Yogyakarta.

Puspawati NM, Simpen IN. 2010. Optimasi deasetilasi kitin dari kulit udang dan cangkang kepiting limbah restoran seafood menjadi kitosan melalui variasi konsentrasi $\mathrm{NaOH}$. Jurnal Kimia. 4(1): 79-90.

Rochima E. 2014. Kajian pemanfaatan limbah rajungan dan aplikasinya untuk bahan minuman kesehatan berbasis kitosan. Jurnal Akuatika. 5(1): 71-82.

Savitri E, N Soeseno, T Adiarto. 2010. Sintesis Kitosan, Poli(2-amino-2-deoksi-D-Glukosa), Skala Pilot Project dari Limbah Kulit Udang sebagai Bahan Baku Alternatif Pembuatan Biopolimer. Dalam: Prosiding Seminar Nasional Teknik Kimia
"Pengembangan Teknologi Kimia untuk Pengolahan Sumber Daya Alam Indonesia. Yogyakarta (ID): 26 Januari 2010.

Siregar EC, Suryati, Hakim L. 2016. Pengaruh suhu dan waktu reaksi pada pembuatan kitosan dari tulang sotong (Sepia officinalis). Jurnal Teknologi Kimia Unimal. 5(2): 37-74. https://doi.org/10. 29103/jtku.v5i2.88

Soltani M, Karimi K, Zamani A. 2017. fungal glucosamine: production, purification, and characterization. International Journal of Research Studies in Biosciences. 5(2): 56-64. https://doi.org/ 10.20431/2349-0365.0501008

Sugita PT, Wukirsari A, Sjahriza, Wahyono D. 2009. Kitosan: Sumber Viomaterial Massa Depan. Bogor (ID): IPB Press.

Wahyuni, Ridhay A, Nurakhirawati. 2016. Pengaruh waktu proses deasetilasi kitin dari cangang bekicot (Achantina fulica) terhadap derajat deasetilasi. Jurnal Riset Kimia. 2(1): 1-7. https:// doi.org/10.22487/j24775398.2016.v2.i1.6039

Wang YS, Shelomi A. 2017._Review of black soldier ly (Hermetia illucens) as animal feed and human food. Foods. 6(91): 1-23.

Wasko A, Bulak P, Berecka MP, Nowak K, Polakowski C, Bieganowski A. 2016. The first report of the physicochemical structure of kitin isolatedfrom Hermetia illucens. International Journal of Biological Macromolecules. 92(2016): 316-320. https:// doi.org/10.1016/j.ijbiomac.2016.07.038

Younes I, Rinaudo M. 2015. Kitin and chitosan preparation from marine sources. Structure, properties and application. Journal Marine Drugs. 13(3): 1133-1174. https://doi.org/10.3390/ md13031133 